International Journal of Social Sciences and Humanities
Available online at http://sciencescholar.us/journal/index.php/ijssh
Vol. 3 No. 3, December 2019, pages: $81 \sim 89$
e-ISSN: 2550-7001, p-ISSN: 2550-701X
https://doi.org/10.29332/ijssh.v3n3.352

\title{
Community-Based Tourism: Measuring Readiness of Artificial Intelligence on Traditional Village
}

\author{
Kadek Ayu Astuti a ${ }^{\text {, Gede Sri Darma }}{ }^{\text {b }}$ \\ Article history: Received 27 April 2019, Accepted: 31 August 2019, Published: 18 November 2019
}

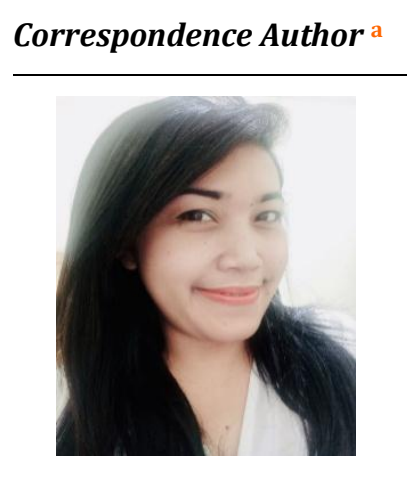

Keywords

advisor;

artificial intelligence;

community;

tourism;

traditional village;

\begin{abstract}
The paper aimed at describing and elaborating the different meanings appear on the description of tourist destinations in two forms. On the one hand is a cyberspace image in two locations tourist destinations, on the other hand, is an image of the real fact after visitor came to a destination place. The research is as the basis of this paper combines two analyses. First, take and analyze the contents from review Trip Advisor and retrieve analytical data from the source www.social-searcher.com. Second, make observations and in-depth interviews of informants who came and witnessed a place of tourist destinations after getting information on digital pages. The analysis of the combined two data attempts to show the uniqueness, the gap, and the difference between cyberspace images of tourist destinations, with the opinions and perceptions of tourist visitors who have seen the real destination. The main aim of this article is to demonstrate the theoretical support of a model about the effect of digital marketing tools technologies on low-density tourism region. In order to achieve this purpose, a literature review will be used as a methodological basis.
\end{abstract}

e-ISSN: 2550-7001, p-ISSN: 2550-701X ${ }^{\odot}$ Copyright 2019. The Author. SS Journals Published by Universidad Técnica de Manabí. This is an open-access article under the CC BY-SA 4.0 license

(https://creativecommons.org/licenses/by-sa/4.0/) All rights reserved.

\section{Contents}

Abstract 81

1. Introduction 82

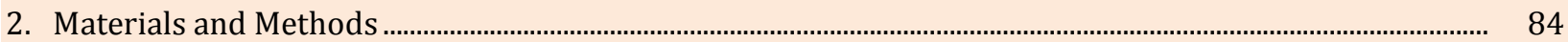

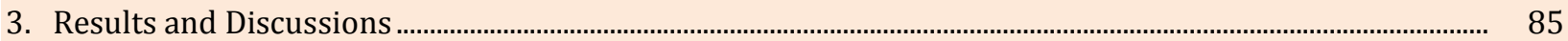

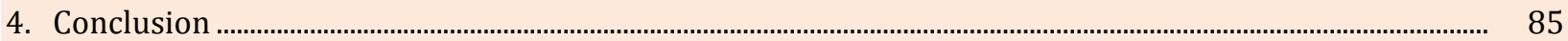

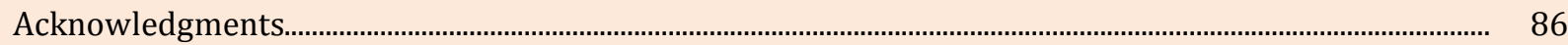

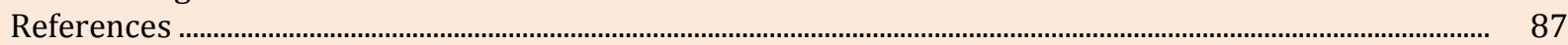

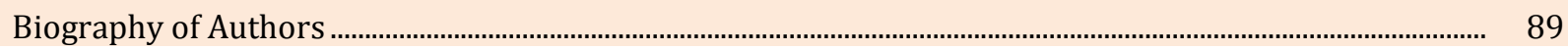

a Undiknas Graduate School, Denpasar, Indonesia

b Undiknas Graduate School, Denpasar, Indonesia 


\section{Introduction}

Utama (2011), explained that tourism has a real positive effect on the country's economy or destination in various ways. However, tourism also hides some things. They are rarely disclosed and calculated. First, it is very difficult to trace its role or loss. Croes \& Vanegas (2008), explained that tourism development can improve country's economy and world. A sector provided opportunities for the movement of various community economic activities. The tourists who visit a country bring foreign exchange to the country. Then, the state will get development funds to boost the economy and eradicate poverty. There is still debate among researchers, non-governmental organizations (NGOs) and development agencies over the effectiveness of the tourism used for poverty reduction (Holden et al., 2011). Blake et al., (2008), explained that the results of tourist visits came were still not optimal on reducing poverty due to uneven economic growth. Second, poverty is a multidimensional concept address not only economic indicators, for example, income, consumption but also non-economic measures unlike living standards, social status, access to education, and health services. Third, empirical evidence related to the effect of tourism on poverty reduction is still rarely revealed. It is in accordance with Croes \& Vanegas (2008); Goodwin (2008); Umrah et al., (2018). However, most academic research only focused on the direct and indirect effect of tourism, for example, the existence of the tourism industry which should contribute to the community. Due to the relationship between tourists and local communities. However, it is not infrequently increase in prices. The destination is sometimes less attention. The victims are local people (Blake, 2008; Spenceley \& Meyer, 2012).

The development of tourism in an area should bring many benefits to the community. There are included economically, socially, and culturally. However, if the development is not properly prepared and managed, it will cause various problems and make it difficult or even detrimental to the community. As it is the case in an area in Trunyan Village. There is part of the tourist destinations in the Kintamani region. Setyadi (2007), explained that the establishment of Tourist Destination Area (TDA) actually showed a priority scale. It is reflected the uneven distribution of tourism activities in Indonesia. The significant increase in tourist visits in the Kintamani area. There was not necessarily have a positive effect on all villages to be able to enjoy benefit from tourism activities equally. This is closely related to the potential and existing infrastructure and directly related to tourism,for example, accommodation, transportation services, services, arts, and attractions, including the socio-cultural environment. They have not been optimally developed even though Trunyan Village is categorized as TDA. It is famous for its unique tourist destinations and cannot be found in other regions. Due to it has a historical "dark tourism" destination with high local wisdom. It does not necessarily make the community feel the benefits of tourism activities. They have lasted a long time having seen from the economic aspect.

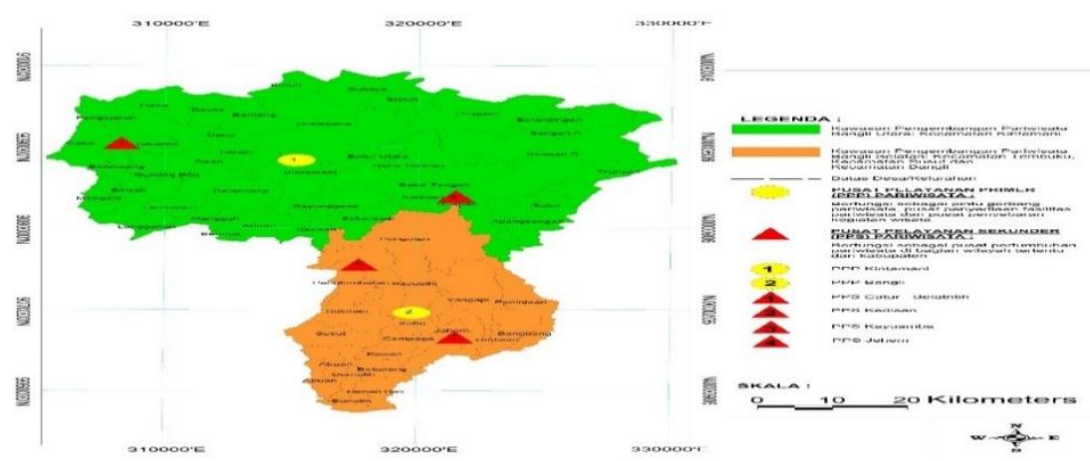

Figure 1. The map of Bangli Regency tourism region structure plan for 2019-2025

The development of the tourist village in Trunyan Village had experienced a tourist crisis. Due to many negative sentiments regarding the tourist attraction. There are to present still some tourists who consider Trunyan grave as a less recommended destination to visit (Umrah et al., 2018). In fact, phenomena, as well as review reviews on Trip Advisor, make the quality of the information sources contained in the reviews given. The consumers have an effect on destination credibility. The given rating online is one way for consumers 
think about product quality as well as destination credibility. It is uploaded to online media. Although sometimes, it is biased in its measurement. It is due to the satisfaction that consumers cannot be measured in terms of product quality but also how consumers are served (Engler et al., 2015).

Rating is a customer's opinion in certain scala. The more stars it gives the better sales ranking (Lackermair et al., 2013). The better rating given will affect the sales level in a content variety (Chevalier \& Mayzlin, 2006; Lin et al., 2011; Park et al., 2007). In accordance with Lim et al., (2010); Mauri \& Minazzi (2013); Park et al., (2007); Sun (2012), stated that customer reviews have a significant effect on product performance. It is described as a consumer purchasing decision. Wang et al., (2015), stated that customer review did not significantly affect purchasing decisions.

The fact on information quality is believed to be one of the truth signals used in online customer reviews (Filieri, 2015). Ryan (2014), explained that the effect of technology identifies changes the affect consumer behavior. Some people are more confident and trusting in information from fellow travelers through personal sites, for example, Blogspot, WordPress or reading reviews. However, there are also some people who have more confidence on the website managed by official agencies. Whether it is a travel agent site or a local government site in the country. They will visit as a benchmark in the validity of information search related to tourist villages (Wisudawati \& Maheswari, 2018). Technological developments contained on social media have led to change on the communication way (Hansen et al., 2010). The current consumers are increasingly actively involved in the creation of products and services. They buy and shift the old paradigm wherein producers used to describe a product and consumers receive it directly. However, the rapid development of technology consumer has begun to get used to finding themselves and determining what they want (Berthon et al., 2007).

The development of information technology finally brings opportunities and challenges to all industries in the business world. The demands to move quickly on adapting to change have an effect on the shorter life cycle of the company. The destination responsibility of the clusters particularly is encouraged to continue, to think, and to act creatively in order to remain competitive. There are only two choices for clusters in the digital age, innovate or die (Yoga \& Hendrawan, 2019).

\section{Literature Review}

Tracing the role of artificial intelligence in digital transformation. The presence of artificial intelligence (AI) in the field of digital marketing can be used for data management, marketing predictions, and enhancing customer experiences. Gentsch (2019), explained that AI lies on the ability to collect data, analyzing, applying and learning it. It has changed digital strategies indirectly unlike (1) Conversational artificial intelligent, (2) AI-powered chatbot for intelligent consumer engagement, (3) Digital touch: filling the gap between brand and customer with right content. On involving $\mathrm{AI}$, the acts as a connecting bridge between tourism producers and tourism potential areas (Zsarnoczky, 2017). In accordance with Suniastha Amerta (2017), mentioned that AI technology is not only a mere technological invention but also an innovation that is the basis for humans to find various information. Therefore, its utilization also varies in various fields. The development of information technology has created a shift in terms of understanding time, behavior on obtaining information quickly and easily (Chen et al., 2016). The development of technology is in terms of information and communication. The tourists also need a reliable source of information about all aspects of travel planning. Starting from booking accommodations to finding the destination that they want to visit (Buhalis \& Law, 2008).

Digital marketing application as a communication strategy. Digital marketing strategies have a very high potential effect on the tourism sector (Buhalis \& Law, 2008). The sector on digital marketing strategies must seek to arouse the interest of consumers or tourists to find more information about tourist destinations and experiences. They can be provided by the objectives of tourist destinations that they want to visit, on the main purpose to inspire them to visit the destinations (Kah et al., 2010). The used websites on the tourism sector play a very important role. They are not only as a tourism promotion activity but also as a source of information for tourists who want to see, find out through the content and presented information (Mandal et al., 2017). The website has an effect on tourist decision making (Ladhari \& Michaud, 2015). It is very possible due to the rapid development of technology. The tourists can write their travel experiences if they feel excited (very satisfied) to social media (Facebook, Twitter, Instagram), personal blogs and chat in forums. They can be

Astuti, K. A., \& Darma, G. S. (2019). Community-based tourism: measuring readiness of artificial intelligence on traditional village. International Journal of Social Sciences and Humanities, 3(3), 81-89. https://doi.org/10.29332/ijssh.v3n3.352 
viewed on the potential tourists who are decisive on influencing the decision of choosing tourist destinations for tourists (Filieri et al., 2015; Reza et al., 2012). The posted comments form perceptions are trusted by tourists during the tourist destination selection process. Arguing on the tourists tend to trust the posted reviews on their peers (Abubakar \& Ilkan, 2016).

Having seen the effect of technology to identify changes that affect consumer behavior. It can be observed through social media. Yoga \& Hendrawan (2019), on multi-channel advertising media showed that the use of social media has provided a platform. They allow marketers to see data in analyzing potential consumer behavior through selected channels as the media used to search information. Interactivity fosters new meaning if it is applied through technology and social media as a consumer dialogue with companies. Therefore, it becomes more active and interactive through digital applications for example websites, e-mails, and the presence of social media unlike Facebook, YouTube, Twitter, and others as marketing tools are important of various economic entities (Batinić, 2015). One of the main reasons for successful digital marketing versus traditional marketing is communication in responding and giving decisions to consumers on real-time (quickly and precisely) certainly through digital media applications (Kaur, 2017). Thus, they need operators who are able to provide information clarity are able to operate the website optimally. Therefore, consumers can get access to information accurately and quickly (Jorge et al., 2018).

Destination Branding on creating 'Sense of Place'. Tourism Products are packaged in a unified series of trips. It can only be enjoyed, if the whole trip series can provide a good experience for people who travel or use the products (Lee et al., 2008). The development of the tourism industry is inseparable from the power of word of mouth (WOM) between travelers on sharing their travel experiences (Abubakar \& Ilkan, 2016). It is not difficult nowadays in digital era to get reliable sources of information about all tourism planning aspects. The internet provides all. There is no more information about an unknown (famous) tourist destination in the world (Litvin et al., 2008). YC Chen et al., (2014), stated that potential tourists who will be traveling can easily access information anywhere and anytime. Of course, planning has been prepared in detail starting from the search for places, costs, time allocation, etc. Therefore, the tour becomes even more enjoyable, the guarantee based on true information.

Bigné et al., (2001), on the destination images, explained that destination images greatly affect tourist satisfaction and tourist loyalty. The more positive image on destination created will affect the tourist's satisfaction for hoping possibility, being willing to visit again and willing to recommend related destinations to others (Çoban, 2012). The brand destination is understood in conveying the value. It is connected to the 'sense of place' on aiming to convey the promise to unforgettable traveling experience (Ritchie, 2003). Thus, the brand destination is a beautiful face built destination to describe the overall destination superiority. The brand is not just a brand destination. There gives value to destinations, brands change ordinary destinations into extraordinary ones (Lee et al., 2008).

The role of clusters on building destination branding. Ritchie (2003), mentioned being a superior and sustainable destination not only from the economic and ecological aspects but as a whole, for example, social, cultural, and political. However, according to Salazar (2012), stated that community-based tourism efforts to create a sustainable tourism industry by prioritizing local people in planning tourism development. In accordance with Morrison (2013), refined the destination management organization (DMO) as a tourism destination governance structure included planning, coordination, implementation, and control of destination organizations in an innovative and systemic way through the use of networks, information, and technology. It is guided in an integrated manner with the community, associations, industry, academia, and the government. In order to improve the quality of management, the volume of tourist visits, length of stay, and the number of tourist expenditures and benefits are for people in tourism destinations.

\section{Materials and Methods}

This research was conducted in Trunyan Village. There is one of the Bali Mula Villages (Desa Asli Bali) that is unique on burying the remains of its dead body. Due to the uniqueness cannot be found elsewhere, Trunyan Village is classified as a dark toursim destination. The selection of informants is carried out using the purposive sampling method. It is the technique of sampling data sources taken based on certain considerations. It is considered to represent the population. This is conducted due to the needed information 
must come from those who know, plan, establish, and oversee strategic decisions made in the tourist village development. Furthermore, through this method, the number of informants who were the data source in this study. There were three clusters responsible for the destination including the government, destination management, and the local community.

Data were obtained using the semi-structured interview method. It is included an in-depth interview category. There was an interview method with more free character questions and allows it to develop as the interview process takes place. The aim is to find data and information more openly. Furthermore, the interview process as an effort to collect data was carried out with the guidance of several questions. They were built based on indicators formed from the theory. It was then dissected more broadly and in-depth based on information obtained from the informants. Data were analyzed using the Miles and Huberman models described the analysis activities starting from the stages of data reduction, data presentation, and data verification. Triangulation of data collection techniques is carried out to measure the credibility testing obtained data. (1) in-depth interviews using semi-structured question guidelines, (2) documentation, and (3) observations that are passive participation, namely, limited to only observe and not get involved on its activities.

\section{Results and Discussions}

This research was conducted in Trunyan Village. There is one of the Bali Mula Villages (Desa Asli Bali) that is unique on burying the remains of its dead body. Due to the uniqueness cannot be found elsewhere, Trunyan Village is classified as a dark toursim destination. The selection of informants is carried out using the purposive sampling method. It is the technique of sampling data sources taken based on certain considerations. It is considered to represent the population. This is conducted due to the needed information must come from those who know, plan, establish, and oversee strategic decisions made in the tourist village development. Furthermore, through this method, the number of informants who were the data source in this study. There were three clusters responsible for the destination including the government, destination management, and the local community.

Data were obtained using the semi-structured interview method. It is included an in-depth interview category. There was an interview method with more free character questions and allows it to develop as the interview process takes place. The aim is to find data and information more openly. Furthermore, the interview process as an effort to collect data was carried out with the guidance of several questions. They were built based on indicators formed from the theory. It was then dissected more broadly and in-depth based on information obtained from the informants. Data were analyzed using the Miles and Huberman models described the analysis activities starting from the stages of data reduction, data presentation, and data verification. Triangulation of data collection techniques is carried out to measure the credibility testing obtained data. (1) in-depth interviews using semi-structured question guidelines, (2) documentation, and (3) observations that are passive participation, namely, limited to only observe and not get involved on its activities.

\section{Conclusion}

Based on the above discussion, the present study offers several suggestions as recommendations can be used as material or secondary data on making strategic decisions related to the development and empowerment in Trunyan Village as a tourist attraction. The recommendations can be offered are as follows:

1) On the geographical mapping in Kintamani area, it should be able to make an itinerary tour on uniting four tourist destinations. They are excellent often visited by tourists, unlike Lake Batur as the main attraction. There are warm-water bathing destinations. It can be found in the toya devasya which does not only offer hot spring baths but also the facilities unlike accommodation for overnight stays. There are batur temple and balingkang palace temple as religious tourism famous for the legendary story of King Sri Jayapangus and Chinese princess Kang Cing We, followed by the famous dark tourism destination in Trunyan Village and Kintamani market as a destination for tourists. Shopping like souvenirs if the four areas can be

Astuti, K. A., \& Darma, G. S. (2019). Community-based tourism: measuring readiness of artificial intelligence on traditional village. International Journal of Social Sciences and Humanities, 3(3), 81-89. https://doi.org/10.29332/ijssh.v3n3.352 
integrated into one tourist destination area. Of course, future expectations will have an effect on two things, spending money because the length of stay increases, the length of stay increases because there are many tourist attractions. They can be visited and this is the role of tourism actor, namely the clusters (government, destination management, and local communities) to want to work together in building excellent tourist destinations in Kintamani area.

2) Optimizing marketing strategies on digital media unlike using inbound marketing. It is integrating website on social media as a promotional tool. Using multi-channel combining inbound and outbound marketing practices on used media through mobile devices, text messages (SMS), e-mails, websites, media social, SEO, or GPS. The support of quality human resources can certainly maximize the role of technology on digital promotion media.

3) Understanding community-based tourism is considered identical to the tourism village has not been optimally implemented in Trunyan Village. The low ability and limited public insight in terms of tourism are separate obstacles. In this case, there are two aspects involved on the internal aspects of technology mastery among government and community. It is lacking thus as not fully implement technology on tourism development from external obstacles is the low ability and limited knowledge of the community in terms of tourism, less equitable participation in the community. As well as the tourist village area not been integrated as a tourist village area. Therefore, Trunyan Village is a less recommended destination as one of the tourist attractions in Kintamani area.

4) Merchandise is needed as a souvenir for visitors who come to visit. On the merchandise visitors will be reminded of the existence of Trunyan village, for example, T-shirts are designed with pictures and tagline writing, canvas tote bags with logo, and tagline designs. Therefore, it will create brand awareness as a tourist destination and history. They have their own uniqueness on the certainly hopes in the future will be interesting tourists to visit again. Thus, as it is to benefit the community economy in Trunyan Village.

\section{Acknowledgments}

The authors would like to thank the reviewer for their consideration of the further process of the present paper. Thanks to the editor of IJSSH for the valuable support, time as well as advice. 


\section{References}

Abubakar, A. M., \& Ilkan, M. (2016). Impact of online WOM on destination trust and intention to travel: A medical tourism perspective. Journal of Destination Marketing \& Management,5(3), 192-201. https://doi.org/10.1016/j.jdmm.2015.12.005

Batinić, I. (2015). The role and importance of internet marketing in modern hotel industry. Journal of Process Management. New Technologies, 3(3), 34-38.

Berthon, P. R., Pitt, L. F., McCarthy, I., \& Kates, S. M. (2007). When customers get clever: Managerial approaches to dealing with creative consumers. Business horizons, 50(1), 39-47. https://doi.org/10.1016/j.bushor.2006.05.005

Bigne, J. E., Sanchez, M. I., \& Sanchez, J. (2001). Tourism image, evaluation variables and after purchase behaviour: inter-relationship. Tourism management,22(6), 607-616. https://doi.org/10.1016/S02615177(01)00035-8

Blake, A. (2008). Tourism and income distribution in East Africa. International Journal of Tourism Research, 10(6), 511-524. https://doi.org/10.1002/jtr.702

Blake, A., Arbache, J. S., Sinclair, M. T., \& Teles, V. (2008). Tourism and poverty relief. Annals of Tourism Research, 35(1), 107-126. https://doi.org/10.1016/j.annals.2007.06.013

Buhalis, D., \& Law, R. (2008). Progress in information technology and tourism management: 20 years on and 10 years after the Internet-The state of eTourism research. Tourism management, 29(4), 609-623. https://doi.org/10.1016/j.tourman.2008.01.005

Chen, J., Teng, L., Yu, Y., \& Yu, X. (2016). The effect of online information sources on purchase intentions between consumers with high and low susceptibility to informational influence. Journal of Business Research, 69(2), 467-475. https://doi.org/10.1016/j.jbusres.2015.05.003

Chen, Y. C., Shang, R. A., \& Li, M. J. (2014). The effects of perceived relevance of travel blogs' content on the behavioral intention to visit a tourist destination. Computers in Human Behavior, 30, 787-799. https://doi.org/10.1016/j.chb.2013.05.019

Chevalier, J. A., \& Mayzlin, D. (2006). The effect of word of mouth on sales: Online book reviews. Journal of marketing research, 43(3), 345-354. https://doi.org/10.1509\%2Fjmkr.43.3.345

Coban, S. (2012). The effects of the image of destination on tourist satisfaction and loyalty: The case of Cappadocia. European Journal of Social Sciences, 29(2), 222-232.

Croes, R., \& Vanegas Sr, M. (2008). Cointegration and causality between tourism and poverty reduction. Journal of Travel Research, 47(1), 94-103. https://doi.org/10.1177\%2F0047287507312429

Engler, T. H., Winter, P., \& Schulz, M. (2015). Understanding online product ratings: A customer satisfaction model.Journal of Retailing and Consumer Services, 27, $113-120$. https://doi.org/10.1016/j.jretconser.2015.07.010

Filieri, R. (2015). What makes online reviews helpful? A diagnosticity-adoption framework to explain informational and normative influences in e-WOM.Journal of Business Research, 68(6), 1261-1270. https://doi.org/10.1016/j.jbusres.2014.11.006

Filieri, R., Alguezaui, S., \& McLeay, F. (2015). Why do travelers trust TripAdvisor? Antecedents of trust towards consumer-generated media and its influence on recommendation adoption and word of mouth. Tourism Management, 51, 174-185. https://doi.org/10.1016/j.tourman.2015.05.007

Gentsch, P. (2019). AI Business: Framework and Maturity Model. In AI in Marketing, Sales and Service (pp. 2778). Palgrave Macmillan, Cham. https://doi.org/10.1007/978-3-319-89957-2_3

Goodwin, H. (2008). Pro-poor tourism: a response. Third World Quarterly, 29(5), 869-871. https://doi.org/10.1080/01436590802215287

Hansen, D., Shneiderman, B., \& Smith, M. A. (2010). Analyzing social media networks with NodeXL: Insights from a connected world. Morgan Kaufmann.

Holden, A., Sonne, J., \& Novelli, M. (2011). Tourism and poverty reduction: An interpretation by the poor of Elmina, Ghana. Tourism planning \& development, 8(3), 317-334. https://doi.org/10.1080/21568316.2011.591160

Jalilvand, M. R., Samiei, N., Dini, B., \& Manzari, P. Y. (2012). Examining the structural relationships of electronic word of mouth, destination image, tourist attitude toward destination and travel intention: An integrated approach.Journal of Destination Marketing \& Management, 1(1-2), 134-143. https://doi.org/10.1016/j.jdmm.2012.10.001

Astuti, K. A., \& Darma, G. S. (2019). Community-based tourism: measuring readiness of artificial intelligence on traditional village. International Journal of Social Sciences and Humanities, 3(3), 81-89. 
Jorge, F., Teixeira, M. S., Correia, R. J., Gonçalves, R., Martins, J., \& Bessa, M. (2018, March). A Conceptual Research Model Proposal of Digital Marketing Adoption and Impact on Low Density Tourism Regions. In World Conference on Information Systems and Technologies (pp. 528-537). Springer, Cham. https://doi.org/10.1007/978-3-319-77703-0_52

Kah, J. A., Lee, C. K., \& Chung, N. (2010). Evaluating travel website motivational communication using a structural equation modelling approach. International Journal of Tourism Research, 12(6), 787-802. https://doi.org/10.1002/jtr.796

Kaur, G. (2017). The importance of digital marketing in the tourism industry. Int. J. Res. GRANTHAALAYAH, 5(6). https://doi.org/10.5281/zenodo.815854

Lackermair, G., Kailer, D., \& Kanmaz, K. (2013). Importance of online product reviews from a consumer's perspective. Advances in economics and business, 1(1), 1-5. https://doi.org/10.13189/aeb.2013.010101

Ladhari, R., \& Michaud, M. (2015). eWOM effects on hotel booking intentions, attitudes, trust, and website perceptions. International Journal of Hospitality Management, 46, 36-45. https://doi.org/10.1016/j.ijhm.2015.01.010

Lee, G., O'Leary, J. T., \& Hong, G. S. (2002). Visiting propensity predicted by destination image: German longhaul pleasure travelers to the US. International Journal of Hospitality \& Tourism Administration, 3(2), 63-92. https://doi.org/10.1300/J149v03n02_04

Lim, E. P., Nguyen, V. A., Jindal, N., Liu, B., \& Lauw, H. W. (2010, October). Detecting product review spammers using rating behaviors. In Proceedings of the 19th ACM international conference on Information and knowledge management (pp. 939-948). ACM. https://doi.org/10.1145/1871437.1871557

Lin, C. L., Lee, S. H., \& Horng, D. J. (2011). The effects of online reviews on purchasing intention: The moderating role of need for cognition. Social Behavior and Personality: an international journal, 39(1), 7181. https://doi.org/10.2224/sbp.2011.39.1.71

Litvin, S. W., Goldsmith, R. E., \& Pan, B. (2008). Electronic word-of-mouth in hospitality and tourism management. Tourism management, 29(3), 458-468. https://doi.org/10.1016/j.tourman.2007.05.011

Mandal, S., Roy, S., \& Raju, A. G. (2017). Exploring the role of website attractiveness in travel and tourism: empirical evidence from the tourism industry in India. Tourism Planning \& Development, 14(1), 110-134. https://doi.org/10.1080/21568316.2016.1192058

Mauri, A. G., \& Minazzi, R. (2013). Web reviews influence on expectations and purchasing intentions of hotel potential customers. International Journal of Hospitality Management, 34, 99-107. https://doi.org/10.1016/j.ijhm.2013.02.012

Morrison, A. M. (2013). Marketing and managing tourism destinations. Routledge.

Park, D. H., Lee, J., \& Han, I. (2007). The effect of on-line consumer reviews on consumer purchasing intention: The moderating role of involvement. International journal of electronic commerce,11(4), 125-148. https://doi.org/10.2753/JEC1086-4415110405

Ritchie, J. B., \& Crouch, G. I. (2003). The competitive destination: A sustainable tourism perspective. Cabi.

Ryan, D. (2014). The best digital marketing campaigns in the World II. Kogan Page Publishers.

Salazar, N. B. (2012). Community-based cultural tourism: Issues, threats and opportunities. Journal of Sustainable Tourism, 20(1), 9-22. https://doi.org/10.1080/09669582.2011.596279

Setyadi, Y. B. (2007). Pariwisata dan perubahan nilai-nilai sosial budaya berdasarkan lingkungan tradisi pada masyarakat bali.

Spenceley, A., \& Meyer, D. (2012). Tourism and poverty reduction: Theory and practice in less economically developed countries. Journal of Sustainable Tourism, 20(3), 297-317. https://doi.org/10.1080/09669582.2012.668909

Sun, M. (2012). How does the variance of product ratings matter?. Management Science, 58(4), 696-707. https://doi.org/10.1287/mnsc.1110.1458

Suniastha Amerta, I. M. (2017). The role of tourism stakeholders at Jasri tourism village development, Karangasem regency. International Journal of Social Sciences and Humanities, 1(2), 20-28. https://doi.org/10.29332/ijssh.v1n2.32

Umrah, D. M., Mahyuni, -, \& Syahdan, -. (2018). Communication strategy for English guides: tourism area in Lombok island. International Journal of Social Sciences and Humanities,2(3), 117-124. https://doi.org/10.29332/ijssh.v2n3.217 
Utama, I. B. G. R. (2011). Dimensi Ekonomi Pariwisata Kajian Dampak Ekonomi Dan Keunggulan Pariwisata Kabupaten/Kota Di Provinsi Bali. Journal of Travel Research, 54(2), 206-221. https://doi.org/10.1177/0047287513514297

Wang, F., Liu, X., \& Fang, E. E. (2015). User reviews variance, critic reviews variance, and product sales: An exploration of customer breadth and depth effects. Journal of Retailing, 91(3), 372-389. https://doi.org/10.1016/j.jretai.2015.04.007

Wisudawati, N. N. S., \& Maheswari, A. I. A. (2018). Potential of Silver Craft Product through to CommunityBased for Tourism Sustainability in Celuk Village. International Research Journal of Management, IT and Social Sciences, 5(1), 9-15.

Yoga, I. M. S., \& Hendrawan, I. G. Y. (2019). Blackbox movies: the transformation of private cinema into multichannel advertising media. International journal of business, economics \& management, 3(1), 41-47. https://doi.org/10.31295/ijbem.v3n1.112

Zsarnoczky, M. (2017). How does Artificial Intelligence affect the Tourism Industry?. VADYBA, 31(2), 85-90.

\section{Biography of Authors}

\begin{tabular}{|l|l|l|}
\hline \hline & $\begin{array}{l}\text { Kadek Ayu Astuti was born on September 08, 1987. She's an Assistant Sales } \\
\text { Manager Cooperate in Alam Kulkul Boutique Resort Kuta Bali and student of } \\
\text { Master Degree Undiknas Graduate School, Denpasar, Indonesia } \\
\text { Email: ayuastuti87@gmail.com }\end{array}$ \\
\hline
\end{tabular}

Astuti, K. A., \& Darma, G. S. (2019). Community-based tourism: measuring readiness of artificial intelligence on traditional village. International Journal of Social Sciences and Humanities, 3(3), 81-89. https://doi.org/10.29332/ijssh.v3n3.352 